\title{
Turismo no Cemitério das Irmandades em Jaguarão/RS - Brasil: um projeto de ensino para desenvolvimento do turismo no espaço cemiterial
}

\author{
Turismo en el Cemitério De Las Hermandades en Jaguarão/RS-Brasil: un \\ proyecto de enseñanza para el desarrollo del turismo en el espacio del
} cementerio

Tourism in the Brotherhood Cemetery in Jaguarão / RS - Brazil: a teaching project to develop tourism in the cemetery

\author{
Charlene Brum Del Puerto ${ }^{1}$ \\ Alice Leoti Silva ${ }^{2}$ \\ Gustavo Rezende Cunha ${ }^{3}$
}

\begin{abstract}
Resumo
Este trabalho traz dados sobre parte do projeto de ensino que foi desenvolvido na Universidade Federal do Pampa (UNIPAMPA) Campus Jaguarão/RS vinculado ao curso de Tecnologia em Gestão de Turismo. Refere-se a uma pesquisa no Cemitério das Irmandades de Jaguarão, para a elaboração de um roteiro turístico. O projeto tem como objetivo principal, a construção de um roteiro dentro do Cemitério das Irmandades para a realização de turismo nesta necrópole. Como objetivos específicos do projeto, busca-se rememorar a história do Cemitério das Irmandades, bem como, estudar, fotografar e catalogar os símbolos da arte, arquitetura e símbolos tumulares presentes no referido cemitério. Metodologicamente, para a pesquisa do projeto, foram utilizadas referências bibliográficas acerca de turismo, turismo em cemitérios e arte/arquitetura/iconografia tumular visando embasar a catalogação desta e a elaboração do roteiro. Quanto a este artigo, objetiva-se relatar a história do cemitério de Jaguarão e apresentar os dados da pesquisa preliminar feita no Cemitério das Irmandades. A pesquisa inicial indicou que o perfil do visitante é formado pelo sexo masculino, com idade entre 25 e 60 , que não tem o hábito de visitar cemitérios com interesse turístico, mas que estariam dispostos e interessados em participar de um roteiro turístico no Cemitério das Irmandades. Nesse sentido, a pesquisa demonstra que há potencial para o desenvolvimento de um roteiro guiado pelo Cemitério das Irmandades no município de Jaguarão/RS.
\end{abstract}

Palavras-Chave: Cemitério das Irmandades; Jaguarão; Patrimônio Cultural; Roteiro Turístico; Turismo em Cemitério.

\footnotetext{
${ }^{1}$ Mestrado em Turismo pela Universidade de Caxias do Sul (UCS); Pelotas, Rio Grande do Sul, Brasil; charlenedelpuerto@bol.com.br. Trabalho apresentado no I Seminário Latino-Americano de Estudos em Cultura - SEMLACult, Foz do Iguaçu/PR, Brasil, 2017.

${ }^{2}$ Mestrado em Memória Social e Patrimônio Cultural; Universidade Federal do Pampa (UNIPAMPA), Jaguarão, Brasil; aliceleoti@ hotmail.com. Trabalho apresentado no I Seminário Latino-Americano de Estudos em Cultura - SEMLACult, Foz do Iguaçu/PR, Brasil, 2017.

${ }^{3}$ Graduando Gustavo Rezende Cunha; Universidade Federal do Pampa (UNIPAMPA), Jaguarão, Brasil; tuti.rezende.cunha@gmail.com. Trabalho apresentado no I Seminário Latino-Americano de Estudos em Cultura - SEMLACult, Foz do Iguaçu/PR, Brasil, 2017.
} 


\begin{abstract}
Resumen
Este trabajo trae datos sobre parte del proyecto de enseñanza que fue desarrollado en la Universidad Federal de Pampa (UNIPAMPA) Campus Jaguarão / RS vinculado al curso de Tecnología en Gestión de Turismo. Se refiere a una investigación en el Cementerio de las Hermandades de Jaguarão, para la elaboración de un itinerario turístico. El proyecto tiene como objetivo principal, la construcción de un itinerario dentro del Cementerio de las Hermandades para la realización de turismo en esta necrópolis. Como objetivos específicos del proyecto, se busca rememorar la historia del Cementerio de las Hermandades, así como, estudiar, fotografiar y catalogar los símbolos del arte, arquitectura y símbolos tumulares presentes en dicho cementerio. Metodológicamente, para la investigación del proyecto, se utilizaron referencias bibliográficas acerca de turismo, turismo en cementerios y arte / arquitectura / iconografía tumular visando basar la catalogación de ésta y la elaboración del itinerario. En cuanto a este artículo, se pretende relatar la historia del cementerio de Jaguarão y presentar los datos de la investigación preliminar hecha en el Cementerio de las Hermandades. La investigación inicial indicó que el perfil del visitante está formado por el sexo masculino, con edad entre 25 y 60, que no tiene el hábito de visitar cementerios con interés turístico, pero que estarían dispuestos e interesados en participar de un itinerario turístico en el Cementerio de las Hermandades. En ese sentido, la investigación demuestra que hay potencial para el desarrollo de un itinerario guiado por el Cementerio de las Hermandades en el municipio de Jaguarão /RS.
\end{abstract}

Palabras claves: Cementerio de las Hermandades; Itinerario Turístico; Jaguarão; Patrimonio Cultural; Turismo en Cementerio.

\begin{abstract}
This work brings data about part of the teaching project that was developed at the Federal University of Pampa (UNIPAMPA) Campus Jaguarão / RS linked to the Technology in Tourism Management course. Refers to a research in the Cemetery of the Brotherhoods of Jaguarão, for the elaboration of a tourist itinerary. The main objective of the project is the construction of a script within the Cemetery of the Brotherhoods to carry out tourism in this necropolis. As specific objectives of the project, it seeks to recall the history of the Cemetery of the Brotherhoods, as well as studying, photographing and cataloging the symbols of art, architecture and tomb symbols present in the cemetery. Methodologically, for the research of the project, bibliographical references about tourism, tourism in cemeteries and art / architecture / iconography were used to base the cataloging of this one and the elaboration of the script. Regarding this article, the objective is to report the history of the cemetery of Jaguarão and presents of the preliminary research done in the Cemetery of the Brotherhoods. The initial survey indicated that the profile of the visitor is formed by the male, aged between 25 and 60, who is not in the habit of visiting cemeteries with tourist interest, but who would be willing and interested in participating in a touristic itinerary in the Cemetery of the Brotherhoods. In this sense, the research shows that there is potential for the development of a script guided by the Cemetery of the Brotherhoods in the municipality of Jaguarão / RS.
\end{abstract}

Keywords: Cemetery of the Brotherhoods; Cultural heritage; Jaguarão; Tour itinerary; Tourism in Cemitério.

\title{
1. Introdução
}

É possível notar que o curso de Gestão de Turismo, campus Jaguarão, carece de espaços para o desenvolvimento de atividades práticas no município de Jaguarão/RS. Nesse sentido, a realização de um projeto de ensino aporta uma significativa ferramenta de ensinoaprendizagem teórico-práticas, desenvolvendo estratégias operacionais que complementam os conteúdos vistos em sala de aula. O projeto fornece ao discente a oportunidade de manusear equipamentos (máquinas fotográficas, GPS, softwares, entre outros), elaborar materiais gráficos e utilizá-los para práticas didático-pedagógicas relacionadas a sua área de formação. Além de ser um projeto educativo envolvendo o Cemitério das Irmandades, o projeto é 
relevante não apenas por beneficiar os discentes do curso de turismo, mas também por ofertar ao município de Jaguarão uma proposta de roteiro turístico, uma atividade de lazer promovendo assim, uma integração entre academia e comunidade local.

O projeto justifica-se pela necessidade de preservação e conservação da memória da comunidade jaguarense, especialmente no que concerne à arte, arquitetura e iconografia tumular, tendo em vista que se considera o Cemitério das Irmandades uma referência de produção de arte para os moradores. A elaboração do roteiro turístico no Cemitério das Irmandades é uma oportunidade de incremento na oferta de atrativos turístico do município de Jaguarão. Até o presente momento a cidade recebe um número significativo de turistas de compras que vão até a cidade vizinha, Rio Branco/Uruguai. A este fluxo de visitantes, podem ser ofertados atrativos culturais, como por exemplo, o roteiro no cemitério.

O projeto de ensino tem como objetivo principal elaborar um roteiro turístico contemplando a história, a arquitetura, a arte e a iconografia tumular do Cemitério das Irmandades no município de Jaguarão/RS. Como objetivos específicos, busca-se rememorar a história do Cemitério das Irmandades a partir da iconografia tumular e; estudar, fotografar e catalogar os símbolos da arte, arquitetura e símbolos tumulares presentes no Cemitério das Irmandades.

Ressalta-se que este artigo apresenta uma parte do projeto de ensino, e assim, objetivase expor ideias que contemple a história dos cemitérios, especificamente a do cemitério de Jaguarão; trazer ideias sobre o turismo em cemitério e; apresentar os dados iniciais da pesquisa feita no Cemitério das Irmandades com 30 participantes, realizada no dia 02 de novembro de 2017 , dia de finados.

\section{Os cemitérios e sua relação com o turismo:}

A palavra cemitério é originária do grego Koimetério e significa 'eu durmo', bem como do latim coemeterium, significando lugar onde se dormia (BORGES, 2002, p. 128). Os cemitérios também são denominados de necrópole, ou seja, a cidade dos mortos. Para Mumford (1998, p.13) "a cidade dos mortos antecede a cidade dos vivos", pois, "Em meio às andanças inquietas do homem paleolítico, os mortos foram os primeiros a ter uma morada permanente: uma caverna, uma cova assinalada por um monte de pedras, um túmulo coletivo".

Na Antiguidade Greco-Romana, surgiu o hábito de deixar alimentos e flores sobre a sepultura do morto, bem como o hábito de fazer a transcrição nas lápides, o que auxiliou para salvaguardar a memória do falecido (HIPÓLITO, 2011). Além de sepultamentos, o cemitério 
era utilizado para outras atividades, como atos jurídicos, danças e jogos (VISSIÈRE, 2013, s/p). Para Vissière (2013) "Com a cristianização da sociedade, surgiu a tendência a aglomerar os defuntos nas proximidades dos lugares sagrados, como tumbas de santos e igrejas, na expectativa do Juízo Final e da ressurreição dos corpos”.

Para Carvalho (2010) os cemitérios surgiram pela necessidade de ter um local para destinar os corpos que "no Brasil, habitaram o chão das igrejas até a metade do século XIX (salvo a exceção de serem estes protestantes ou escravos)" (CARVALHO, 2010, p. 540). As orientações higienistas surgidas no século XIX criaram leis proibindo os sepultamentos nas igrejas ou templos buscando evitar a propagação de miasmas. Vouvelle (1997, p.352) expõe que [na Europa] “somente em 1851 o Intermect Act (Lei Funerária) proibiu o sepultamento no interior das igrejas”. Segundo Borges (2002), as autoridades religiosas geriram os primeiros cemitérios, impulsionando com isto, a utilização de imagens devocionais (BORGES, 2001).

[...] mesmo com a perda da influência política, a igreja manteve-se fiel aos seus dogmas tradicionais, diante da morte e da existência espiritual. Desse modo os cemitérios convencionais seculares guardam em seu bojo uma arquitetura sacra. Os túmulos empregam com frequência fórmulas piedosas em seus epitáfios, símbolos cristãos nos adornos e imagens devocionais das mais simples as mais luxuosas. (BORGES, 2001 p. 10-11)

Com isto outra arte tumular, além da sacra, se expandiu. No Brasil, a arquitetura europeia influenciou a arte funerária do país. Ressalta-se, no entanto que, na atualidade, há um distanciamento na relação em que os vivos mantêm dos mortos e este fato é exposto por Borges (2002, p.120)

[...] a relação entre o morto e seus descendentes sobreviventes vai-se esvaecendo aos poucos, alcançando, quando muito, a terceira geração ascendente. Hoje os túmulos do século XIX encontram-se nas mãos dessa geração, daí estarem eles descaracterizados e/ou em estado sofrível.

Ainda assim, os espaços fúnebres são significativos para marcar parte da trajetória de vida do morto e a memória dos descendentes sobre o falecido. Nesse sentido, Del Puerto (2015, p. 46) afirma que

[...] consolidaram-se os cemitérios, como campos de registros de morte. Ao mesmo tempo, eles também se constituem como campo de inscrição de vida, de vida que passou, mas cuja energia, essência, encontra-se ali, inscrita, na lembrança e nos diversos elementos expressivos que marcam essa vida. Esses registros, por sua vez, correspondem tanto à singularidade de trajetórias individuais, quanto aos modos de vida e de representação artística de diferentes sociedades. O modo de velar e de sepultar os mortos também é expressão da inscrição de uma cultura. Os elementos 
que caracterizam o espaço desse sepultamento também nos revelam dados sobre a arte e o modo de vida das populações do lugar.

Assim, os espaços cemiteriais entendido como guardião da memória da família, estende-se também como detentor de informações sobre arte, arquitetura, costumes e modo de vida de uma determinada população. Nesse contexto, insere-se o Cemitério das Irmandades no município de Jaguarão/RS, já que este, conta parte da história da cidade e suas personalidades, além de demonstrar através de iconografias o poder econômico, o papel social e parte da história de vida de seus moradores. Por este motivo, considera-se o Cemitério das Irmandades como um museu a céu aberto

[...] as construções tumulares dentro dos cemitérios públicos e privados revelam essa preocupação de preservar a memória através de obras de renomados artistas plásticos, túmulos de personalidades de relevância, textos e outros traços que contam a história das pessoas ali enterradas, tornando o espaço um museu ao céu aberto (ARAUJO, 2013, p. 1).

A preservação da memória tumular do Cemitério das Irmandades insere-se como elemento essencial e representativo da história de Jaguarão, já que está imbuído nas formas de produção da cultura da sociedade jaguarense. Configurando-se como patrimônio cultural edificado permeada por símbolos presentes na iconografia e que carece de registro. $\mathrm{O}$ patrimônio cultural pode ser definido como um bem material ou imaterial que possui significado e importância artística, estética, cultural, religiosa, documental e/ou memorial para uma determinada sociedade. Nesse sentido, Prats (1998, p. 63) afirma que o patrimônio cultural é "todo aquello que socialmente se considera digno de conservación independientemente de su interés utilitario. (...) El patrimonio cultural es una invención y una construcción social". O patrimônio cultural é um elemento com a capacidade de destacar e fornecer subsídios para a compreensão da identidade de uma sociedade, já que é um dos elementos que se destacam na constituição de uma identidade cultural. Ele impulsiona a cultura compartilhada e as experiências vivenciadas.

Nessa perspectiva, os patrimônios culturais podem ver vistos como lugares que guardam a memória e assim são "a construção dessa forma de obrigação em relação à presença material do passado" (POULOT, 2008, p. 27). Especificamente nos cemitérios, também denominados campos santos e necrópoles, inúmeros são as formas de patrimônio expressas. Frente ao registro destes patrimônios relata-se a importância do Instituto do Patrimônio Histórico e Artístico Nacional (IPHAN), o qual realiza tombamentos de bens funerários desde 1930, conforme expõe Castro (2008, p.2) 
[...] já existem desde a década de 1930 tombamentos específicos de cemitérios ou de partes de conjuntos funerários como, por exemplo, túmulos, estátuas funerárias e portões de entrada, realizados por este órgão. São elementos que formam o patrimônio funerário brasileiro, entendido no contexto desta análise, como conjunto de elementos materiais e imateriais presentes em locais de sepultamentos ou cemitérios. (CASTRO, 2008, p. 2)

Este registro sobre os bens fúnebres indicam a importância social que os artigos funerários possuem. Nos arquivos do IPHAN, desde a década de 1930, existem ações de preservação de 15 artigos fúnebres, conforme aponta Castro (2008). Em nova pesquisa nos dados disponibilizados pelo IPHAN, até o momento, o número de artigos fúnebres tombados, não havia sido alterado. O primeiro item foi tombado em 1930 e o último em 2000. Neste período foram registrados pelo IPHAN (Quadro 1): igrejas, cemitérios, museu de arte sacra, inscrições tumulares em igrejas, capela, convento, lápide tumular, túmulo, portão de cemitério, conjunto arquitetônico e paisagístico que incluem cemitério, estátua de mausoléu e lugar de sepultamento. Todos estes, diretamente relacionados à temática tumular. Até o ano de 2008 alguns itens funerários haviam recebido autorização para tombamento junto ao IPHAN, porém não haviam sido inscritos nos livros ao qual foram indicados. Em nova pesquisa na página do IPHAN, no ano de 2017 os dados referentes à inscrição, não foram encontrados.

Quadro 1: Informações sobre os itens fúnebres tombados pelo IPHAN

\begin{tabular}{|c|c|c|c|c|c|c|}
\hline Denominação & Década & Cidade/UF & Região & $\begin{array}{c}\text { Participação } \\
\text { no pedido }\end{array}$ & $\begin{array}{c}\text { Tipo de } \\
\text { Tombamento }\end{array}$ & $\begin{array}{c}\text { Livros de } \\
\text { Tombo }\end{array}$ \\
\hline $\begin{array}{c}\text { Igreja de São Francisco } \\
\text { da Penitência, Cemitério e } \\
\text { Museu de Arte Sacra }\end{array}$ & 1930 & $\begin{array}{c}\text { Rio de } \\
\text { Janeiro/RJ }\end{array}$ & Sudeste & Parte & Convencional & $\begin{array}{c}\text { Histórico Belas } \\
\text { Artes }\end{array}$ \\
\hline Cemitério do Batalhão & 1930 & $\begin{array}{l}\text { Campo } \\
\text { Maior/PI }\end{array}$ & Nordeste & Objeto & Local & $\begin{array}{c}\text { Histórico Belas } \\
\text { Artes } \\
\end{array}$ \\
\hline $\begin{array}{l}\text { Inscrições tumulares da } \\
\text { Igreja da Vitória }\end{array}$ & 1930 & Salvador/BA & Nordeste & Objeto & Elementos & Belas Artes \\
\hline $\begin{array}{c}\text { Capela de São Pedro e } \\
\text { Cemitério de Maruí }\end{array}$ & 1940 & Niterói/RJ & Sudeste & Parte & Convencional & Belas Artes \\
\hline $\begin{array}{c}\text { Convento e Igreja de } \mathrm{N}^{\mathrm{a}} \\
\mathrm{S}^{\mathrm{a}} \text { dos Anjos, Cruzeiro, } \\
\text { Capela e Cemitério da } \\
\text { Ordem Terceira de São } \\
\text { Francisco } \\
\end{array}$ & 1950 & Cabo Frio/RJ & Sudeste & Parte & Convencional & Belas Artes \\
\hline $\begin{array}{l}\text { Lápide tumular de Estácio } \\
\text { de Sá }\end{array}$ & 1950 & $\begin{array}{c}\text { Rio de } \\
\text { Janeiro/RJ }\end{array}$ & Sudeste & Objeto & Elementos & Histórico \\
\hline $\begin{array}{l}\text { Cemitério de Nossa } \\
\text { Senhora da Soledade }\end{array}$ & 1960 & Belém/PA & Norte & Objeto & Convencional & $\begin{array}{c}\text { Arqueológico, } \\
\text { etnográfico e } \\
\text { paisagístico }\end{array}$ \\
\hline
\end{tabular}


RELACult - Revista Latino-Americana de Estudos em Cultura e Sociedade

Revista Latinoamericana de Estudios en Cultura y Sociedad | Latin American Journal of Studies in Culture and Society V. 04, ed. especial, fev., 2018, artigo no 791 | relacult.claec.org | e-ISSN: 2525-7870

\begin{tabular}{|c|c|c|c|c|c|c|}
\hline $\begin{array}{c}\text { Túmulos do Dr. Pedro } \\
\text { Lund e seus } \\
\text { colaboradores }\end{array}$ & 1960 & $\begin{array}{c}\text { Lagoa } \\
\text { Santa/MG }\end{array}$ & Sudeste & Objeto & Local & Histórico \\
\hline $\begin{array}{c}\text { Portão do Cemitério de } \\
\text { Arez }\end{array}$ & 1960 & Arez/RN & Nordeste & Objeto & Elementos & Histórico \\
\hline $\begin{array}{c}\text { Cemitério Protestante (ou } \\
\text { do Imigrante) }\end{array}$ & 1960 & Joinville/SC & Sul & Objeto & Convencional & $\begin{array}{l}\text { Histórico, } \\
\text { Arqueológico, } \\
\text { etnográfico e } \\
\text { paisagístico }\end{array}$ \\
\hline $\begin{array}{c}\text { Estátua do Mausoléu da } \\
\text { família do Barão de } \\
\text { Cajaíba }\end{array}$ & 1960 & Salvador/BA & Nordeste & Objeto & Elementos & Belas Artes \\
\hline $\begin{array}{l}\text { Porto Seguro, conjunto } \\
\text { arquitetônico e } \\
\text { paisagístico }\end{array}$ & 1970 & $\begin{array}{c}\text { Porto } \\
\text { Seguro/BA }\end{array}$ & Nordeste & Parte & Convencional & $\begin{array}{c}\text { Histórico, } \\
\text { Arqueológico, } \\
\text { etnográfico e } \\
\text { paisagístico }\end{array}$ \\
\hline $\begin{array}{l}\text { Conjunto Arquitetônico e } \\
\text { Paisagístico da cidade de } \\
\text { Mucugê, especialmente o } \\
\text { Cemitério }\end{array}$ & 1980 & Mucugê/BA & Nordeste & Parte & Convencional & $\begin{array}{c}\text { Arqueológico, } \\
\text { etnográfico e } \\
\text { paisagístico }\end{array}$ \\
\hline $\begin{array}{c}\text { Cemitério da Candelária } \\
\text { (Estrada de Ferro Madeira } \\
\text { Mamoré) }\end{array}$ & 2000 & $\begin{array}{c}\text { Porto } \\
\text { Velho/RO }\end{array}$ & Norte & Objeto & Convencional & $\begin{array}{l}\text { Tombamento } \\
\text { aprovado, mas } \\
\text { ainda sem } \\
\text { inscrição }\end{array}$ \\
\hline $\begin{array}{c}\text { Lugar de sepultamento do } \\
\text { Guia Lopes, o Cel. } \\
\text { Camisão e o Ten. Cel. } \\
\text { Juvêncio }\end{array}$ & 2000 & Jardim/MS & $\begin{array}{l}\text { Centro- } \\
\text { oeste }\end{array}$ & Objeto & Local & $\begin{array}{c}\text { Tombamento } \\
\text { aprovado, mas } \\
\text { ainda sem } \\
\text { inscricão }\end{array}$ \\
\hline
\end{tabular}

Fonte: Adaptação a partir quadro elaborado por Castro (2008). Os tombamentos identificados como "ainda sem inscrição" permanecem nessa situação até o presente momento, conforme observação do último arquivo sobre os tombamentos (2012) disponibilizados pelo IPHAN (2017).

O tombamento e manutenção destes itens são significativos para o desenvolvimento da atividade turística. Neste sentido as diferentes interpretações sobre turismo e cemitérios, são importantes para se pensar o turismo nos espaços cemiteriais. Internacionalmente os cemitérios utilizados para a atividade turística são: Montparnasse, Montmatre, Père Lachaise/França; Cemitério Nossa Senhora de Almudena e Cemitério de Poblenau/Espanha; Cemitério Staglieno/Itália; Cemitério Judeu de Praga/República Checa; Cemitério Săpânţa/Romênia; La Recoleta/Argentina; Necrópoles Cristóbal Colón/Cuba; etc .

No Brasil, os cemitérios mais conhecidos pela atividade turística são: Cemitério São João Batista, situado no Rio de Janeiro, e Cemitérios da Consolação e Araçá, localizados na cidade de São Paulo, seja pela história, arte, personalidade ou fé. Pode se mencionar, ainda, aqueles cemitérios visitados especificamente em função da fé, onde a crença em alguns santos populares mobilizam os visitantes (DEL PUERTO, 2016, p. 34). 
No Brasil, observa-se que os cemitérios são considerados uma opção dentro o rol de atrativos turísticos que o país possui, porém de forma bastante tímida. No Rio Grande do Sul, também há visitações em cemitérios principalmente por motivações relacionadas à fé nos santos populares

\begin{abstract}
Maria Isabel Hornos, a Guapa, é cultuada como santa do povo em São Gabriel, desde que foi assassinada, no carnaval de 1924. Outras cidades do Interior também têm seus santos populares, como a cigana Terena Carraro, de Pelotas, e a jovem Maria Elizabeth de Oliveira, que atrai caravanas todos os anos a Passo Fundo. [...] Seu túmulo guarda hoje várias placas de pessoas que acreditam terem promessas atendidas pela Guapa. [...] No Cemitério Ecumênico São Francisco de Paula [...] Segundo os funcionários mais antigos do cemitério, o culto a Terena Carraro começou há cerca de 20 anos. Atualmente, o jazigo é o mais visitado, tanto na época de Finados como durante todo o ano. O túmulo, na parte mais antiga do cemitério, está sempre limpo e decorado com flores e oferendas de fiéis que acreditam em seus milagres e graças. Em Passo Fundo, o cemitério da vila Vera Cruz recebe durante todo o ano caravanas de outros estados e até de países vizinhos. Os devotos buscam o túmulo de Maria Elizabeth de Oliveira, que morreu jovem, em 1965, vítima de acidente, e é considerada milagreira. Os fiéis costumam adornar o lugar com rosas vermelhas pois, segundo eles, as graças vêm precedidas pelo perfume da flor. (CORREIO DO POVO, 1998, p. 16)
\end{abstract}

Em relação aos conceitos referentes ao turismo em cemitério, Hahne (2010, p.37) expõe como: “[...] turismo mórbido, também conhecido como turismo negro, turismo sombrio, turismo necrófilo, turismo inusitado, turismo macabro, turismo de fait divers, entre outras denominações”. Conforme Ferreira (2009, p.350), o turismo de fait divers ou turismo necrófilo pode ser entendido como "[...] aquele no qual as pessoas são atraídas a visitar os lugares relacionados à dor e à morte, sejam eles cemitérios, memoriais, ou mesmo lugares onde ocorreram tragédias - genocídios, batalhas, etc".

No entanto, o turismo em cemitério não está sempre relacionado à morte, visto que também se busca nestes locais a fruição da arte, da história e do lazer, haja vista que em muitos países são realizadas diversas atividades no interior dos cemitérios, como sessão de cinema, piqueniques, apresentações teatrais e outros. É o que aponta Afonso (2010, p. 16): “[...] percebe-se que o uso do espaço cemiterial apresentado de forma diferenciada, fugindo da função para o qual foi concebido, retira a intencionalidade dada na criação do cemitério e cria uma nova forma de lazer, escapando do lazer mercadoria [...]”.

Borges (2002,p.148) explica que o turismo em cemitério iniciou em 1980, momento em que "[...] surgiu o modismo de se visitar cemitérios importantes na Europa e nos Estados Unidos. No entanto, conforme Queiroz (2007), é a partir de 1990 que há aumento pela visitação turística nos cemitérios. 
Del Puerto (2016) aponta que, se o cemitério for entendido como um espaço de cidadania, cultura entre outros, ou seja, um campo de significações humanas é possível entender a utilização dos espaços fúnebres no turismo. Trazendo a ideia de turismo cultural como uma das principais vertentes do turismo, é possível associá-la ao turismo em cemitério, potencializando assim, a interpretação cultural dos visitantes frente aos espaços fúnebres. Para Barretto (1995), o turismo cultural é aquele que não tem como atrativo principal um recurso natural, portanto, ele tem como objetivo o conhecimento de bens materiais e imateriais produzidos pelo homem, o patrimônio cultural.

No turismo cultural, o visitante busca investigar a história do local por meio do patrimônio cultural material/imaterial e assim aproveitar seu tempo destinado à atividade turística. Por essa razão, é mister a efetivação de um roteiro turístico no Cemitério das Irmandades, especialmente quando se trata de uma atividade que visa a preservação e a conservação do patrimônio cultural de Jaguarão. Nessa perspectiva, as ações devem-se voltar aos cidadãos e aos turistas que visitam o município, motivando-os para conhecer e proteger local onde vivem e visitam através do processo de apropriação do bem cultural coletivo.

\section{Cemitério das Irmandades}

Após a cólera defasar centenas de pessoas na cidade de Jaguarão, foi proposta pelo comerciante José Alberto Portella a criação de um novo cemitério, de interesse particular. O projeto foi iniciado através de doações realizadas pelo Augusto Cezar de Leivas, Padre Themudo Cabral e o próprio José Alberto Portella, sendo destinada a Irmandade Nossa Senhora da Conceição e a Irmandade Santíssimo Sacramento, de um espaço total de 40.000 $\mathrm{m}^{2}$. Antes mesmo de sua inauguração, o cemitério já era conhecido por ser o "novo Campo Santo" e já abrigava corpos que haviam sido transladados do antigo cemitério municipal, localizado no centro da cidade.

Após a doação do campo Santo, as irmandades tiveram desentendimentos na construção do cemitério da cidade, como a localização, arquitetura e até mesmo a posse dos defuntos. Foi então definida uma divisão pelo Padre João Themudo, através de uma ata, fazendo com que a configuração do local ficasse o lado direito de quem entra, pertencendo a Irmandade da Nossa Senhora da Conceição e o lado esquerdo da Irmandade do Santíssimo Sacramento (MARTINS, 2001).

O campo Santo demorou mais de dois anos para ser inaugurado, fazendo com que durante este tempo, os mortos que foram vítimas da doença, que não fossem negros, e os que tinham direito a usar o novo terreno através da compra do espaço, fossem levadas ao novo 
local, ainda em construção, visto que o antigo cemitério estava com a área totalmente preenchida (SOARES, 2011). Feita a divisão no interior do cemitério, a configuração do local ficou disposta da seguinte forma: na posição de quem entra, o lado direito pertence à Irmandade da Nossa Senhora da Conceição e o lado esquerdo da Irmandade do Santíssimo Sacramento (MARTINS, 2001).

\section{Procedimentos metodológicos}

A metodologia utilizada no projeto em desenvolvimento aplica as teorias dos componentes curriculares como: Rotas e Roteiros, Turismo e Hospitalidade, Turismo e Patrimônio, Turismo Cultural e Museus, dentre outros, aliada a momentos de avaliações das ações, com análise dos pontos positivos e negativos das propostas no decorrer do projeto. As ações estão em consonância com a gestão do campus, e as normas vigentes na universidade. As etapas do projeto estão sendo registradas em planilha de avaliação pelos participantes, relatórios e documentadas através de fotografias, as quais serão disponibilizadas na página do curso de Tecnologia e Gestão de Turismo.

Os procedimentos metodológicos estão divididos nas seguintes etapas: pesquisa bibliográfica e documentos, a fim de conhecer a história do Cemitério das Irmandades; e pesquisa de campo com o escopo de registrar fotograficamente a arquitetura, arte e iconografia tumular; posteriormente, serão catalogados os registros; e, após passa-se a etapa de elaboração o roteiro turístico e ofertado a comunidade local como uma proposta piloto. Até o presente momento, foi realizada a pesquisa bibliográfica, bem como uma pesquisa em campo, realizada no Cemitério das Irmandades no dia 2 de novembro de 2017, tendo iniciado às $9 \mathrm{~h}$.

A pesquisa bibliográfica parte das temáticas de arte e iconografia tumular, patrimônio, turismo em cemitérios, história dos cemitérios, cemitérios e espaços de memória e seus desdobramentos. Para a pesquisa de campo foram aplicados 30 (trinta) questionários com 10 (dez) perguntas abertas (Quadro 2), e o método de abordagem foi aleatório, assim estando condicionada a disponibilidade dos entrevistados.

Quadro 2: Questões da pesquisa aplicada no Cemitério das Irmandades

\begin{tabular}{|l|l|}
\hline & Questões \\
\hline 1 & Sexo: \\
\hline 2 & Idade: \\
\hline 3 & Local de Moradia: (Jaguarão ou outras cidades): \\
\hline
\end{tabular}




\begin{tabular}{|l|l|}
\hline 4 & Por quais motivos vai ao cemitério? \\
\hline 5 & O que lhe chama atenção no cemitério? \\
\hline 6 & $\begin{array}{l}\text { Costuma "passear" pelo cemitério, ou já visitou algum cemitério para visitar túmulos de pessoas } \\
\text { famosas ou ver a arte tumular? Onde? }\end{array}$ \\
\hline 7 & Se houvesse um roteiro turístico no cemitério o Sr (a) participaria? Por quê? \\
\hline 8 & O que esperaria ver nessa visitação? \\
\hline 9 & Concorda com a visitação a este cemitério para atividade turística? Por quê? \\
\hline 10 & Que túmulo considera interessante o visitante conhecer? \\
\hline
\end{tabular}

Fonte: adaptada de Del Puerto (2013)

O dia da aplicação de pesquisa foi escolhido pelo fato de ser o dia de finados (dia de homenagear as pessoas falecidas), pois deste modo, oportunizou uma quantidade significativa de fluxo de visitantes no Cemitério das Irmandades. Quanto ao horário, optou-se por aplicar o questionário no turno da manhã, iniciando às 9h porque este é o horário da missa católica dedicada ao dia de finados que ocorre na capela dentro do Cemitério das Irmandades.

\section{Descrição e análise de dados}

Através da pesquisa pode-se afirmar que a maior parte dos respondentes é do sexo masculino (16 questionados, sendo $53 \%$ do público). O público participante da pesquisa possui a seguinte faixa etária: até 25 anos de idade, representando 17\%; até 60 anos de idade representando 63\% (maior parte dos entrevistados); e, com mais de 60 anos de idade representando $20 \%$ dos questionados. A partir destas informações pode-se traçar um perfil inicial dos visitantes no Cemitério das Irmandades de Jaguarão, caracterizado majoritariamente por homens adultos até 60 anos.

Ainda se tratando do perfil dos visitantes, a pesquisa indicou que $90 \%$ destes, são moradores do município. Os demais visitantes eram oriundos de Pelotas, Arroio Grande e Pedras Altas, municípios localizados no Rio Grande do Sul, geograficamente próximos e pertencentes à mesma região turística, a Costa Doce.

Quanto ao motivo da visita observou-se que $80 \%$ dos participantes relataram a visita para homenagem e recordação do ente querido. Ressalta-se que nenhum dos entrevistados mencionou ir ao cemitério para visitação de amigos, ou devoção a algum santo popular. Os santos populares costumam ser comumente encontrados nas necrópoles, no entanto, durante a pesquisa em campo, não foi encontrado nenhum túmulo que pudesse ser caracterizado como de um santo popular. As outras motivações para visitar o Cemitério das Irmandades foram à tradição, o sentimento pelo ente falecido, e um entrevistado afirmou que vai ao cemitério por 
obrigação com os familiares falecidos bem como com os familiares vivos. Esta afirmação vai ao encontro das palavras de Borges (2002, p.120) quando a mesma afirma que a "relação entre o morto e seus descendentes sobreviventes vai-se esvaecendo aos poucos, alcançando, quando muito, a terceira geração ascendente.”. Foram descritas outras motivações, como participar da missa que é celebrada no dia de finados, e quando da ocasião de velórios e sepultamentos de familiares, e neste caso também de amigos.

$\mathrm{Na}$ questão seguinte, foi solicitado aos participantes da pesquisa que apontassem aquilo que lhes chamava atenção no Cemitério das Irmandades. Nesta questão, as respostas foram bastante diversificadas, assim, para melhor compreensão, foram compiladas as respostas que usaram diferentes termos, mas que remetiam a um mesmo sentido. As respostas que despertaram atenção foram que $30 \%$ dos questionados afirmaram que "nada" lhes despertava atenção no Cemitério. A resposta "nada" se desdobravam com outras afirmações, como: que visitavam somente os túmulos de familiares, ou que tinham medo de ir a cemitérios e, por fim que o Cemitério das Irmandades não tinha nada de diferente que lhe chamasse a atenção. Ao cruzar esta informação com a pergunta anterior, que trata acerca da motivação, observa-se que todos respondentes que afirmaram que nada despertava atenção, também afirmaram que a motivação para ir ao cemitério estava ligada à visitação aos túmulos de familiares falecidos.

Ainda acerca do questionamento sobre o que chama atenção no Cemitério das Irmandades, dois entrevistados associaram o Cemitério a lugar de paz e silêncio. Outros dois entrevistados afirmaram que ali é um local organizado, limpo e conservado. Já outros entrevistados não têm a percepção tão positiva sobre o Cemitério das Irmandades, uma vez que responderam que alguns jazigos possuem a aparência de estarem em situação de abandono, novamente Borges (2002, p.120) relata que "Hoje os túmulos do século XIX encontram-se nas mãos dessa geração, daí estarem eles descaracterizados e/ou em estado sofrível.”. E, ainda que o atendimento dos funcionários é péssimo, sendo uma resposta para cada item. Dois entrevistados usaram fizeram uso dos termos "beleza, ostentação e luxo" quando descreveram o que despertava atenção de que quem visitava o cemitério, assim associando ao senso comum entre os moradores de Jaguarão que afirmam o Cemitério das Irmandades é o "cemitério dos ricos", enquanto que o cemitério municipal seria o "cemitério dos pobres". Esta resposta alia a ideia de que o cemitério pertence a uma classe de alto poder econômico de Jaguarão, pois este seria um espaço dedicado àqueles que possuem poder econômico e/ou político. 
Quatro participantes fizeram referência à antiguidade dos túmulos e jazigos que se encontram no Cemitério das Irmandades. Outros também utilizaram palavras que remetiam a temporalidade, como: a arte, a arquitetura, a história, as obras de arte, esculturas, estrutura cemiterial e o amor que algumas pessoas têm pela estética tumular. Nesse contexto, estes participantes demonstraram a compreensão da importância histórica, arquitetônica e patrimonial que a arte e iconografia tumular possuem. E, que elas são capazes de guardar a memória social, sendo entendida como um patrimônio cultural. E, através dele contar parte de uma história de Jaguarão e das pessoas que nela viveram um período de pujança e opulência.

Quando questionados se tinham o hábito de visitar cemitérios com o objetivo de conhecer túmulos de personalidades famosas ou para ver a arte tumular, majoritariamente os participantes afirmaram que não, sendo $70 \%$ deles. Esta resposta indicam que os cemitérios ainda são vistos, por parte da população brasileira, como um lugar de morte e pesar. No entanto, $30 \%$ dos participantes afirmaram que costumam frequentar cemitérios, além do Cemitério das Irmandades, como por exemplos os cemitérios de: Pelotas, Arroio Grande, Rio Grande, Rio Branco (UY), Montevidéu (UY) e Recoleta (Buenos Aires/AR). Estes dois últimos, segundo os entrevistados, com o objetivo exclusivo de fazer visitação turística.

A questão seguinte buscou saber se haveria interesse em visitar o Cemitério das Irmandades, caso fosse criado um roteiro de visitação ao local. Apenas 5 (cinco) entrevistados disseram que não tinham o interesse de participar de tal visitação. Já os demais entrevistados, representando aproximadamente $83 \%$ deles, afirmaram que gostariam de fazer este roteiro. De acordo os mesmos seria uma experiência interessante uma vez que seria uma forma de obter informação e conhecimento sobre a história do município e do cemitério, além de compreender a arte tumular, o patrimônio histórico-cultural e a arquitetura presente no Cemitério das Irmandades. Importante destacar que, grande parte dos que responderam que tinham vontade de fazer o roteiro, também disseram não ter o hábito de fazer visitação turística a cemitérios.

Apesar de alguns entrevistados já haverem dito o que esperavam dessa visitação, o questionário previu uma pergunta exclusivamente com esse intuito. Dos questionados, 20\% não souberam responder o questionamento. Possivelmente, o não saber responder possa estar relacionado à falta de hábito de fazer visitação turística a cemitérios. No entanto, $80 \%$ responderam a questão. Grande parte das respostas versava no fato de que eles esperam conhecer os aspectos históricos do Cemitério das Irmandades, bem como a sua arte, simbolismo, arquitetura, beleza do local, e a história das personalidades do município que ali estão inumadas. 
Dentre as pessoas que souberam responder $(80 \%)$, quatro respostas se diferenciaram das demais: uma disse que espera que o roteiro seja ofertado durante a feira do livro e que tenha missa dentro do Cemitério das Irmandades; outra afirmou que uma visitação turística é interessante para saber quais as pessoas jovens que haviam falecido recentemente, e que ela não via mais circulando pela cidade; já outro entrevistado afirmou que espera que seja um roteiro que contemple todo o município, e não apenas o cemitério; em por fim, um entrevistado afirmou que acredita que um bom roteiro no cemitério deveria incluir rezas e cantos religiosos. Demonstra-se assim, o sentimento de fé. Apesar de não ter sido identificado nenhum santo popular no cemitério, a fé continua sendo um motivador para o deslocamento de visitantes.

Na penúltima questão, indagou-se aos participantes da pesquisa se eles concordavam com a ofertada de uma visitação turística no Cemitério das Irmandades. Apenas 4 (quatro) pessoas se mostraram contrárias a proposta, uma vez que impactaria as pessoas e porque acreditam que não haveria público para fazer tal visitação. Porém 86,7\% dos participantes disseram concordar com a realização de visitação turística no Cemitério das Irmandades. De acordo com os questionados, um roteiro turístico é uma ótima ideia para a valorização da história e cultura do município de Jaguarão, pois além de ter um potencial turístico, seria uma forma de criação de emprego e renda para os moradores da cidade.

E, por fim, como a último questionamento, foi solicitado aos participantes da entrevista que sugerissem arte ou sepulturas a serem incluídas no roteiro turístico que está sendo elaborado. Metade dos entrevistados não soube responder a solicitação, o que pode indicar que estes visitantes, não conhecem parte da história do local visitado, ou também, que não reconhecem o espaço fúnebre como um local capaz de conter aspectos que exponham a história do município de Jaguarão. A outra metade apresentou inúmeros túmulos, como: dos ex-prefeitos de Jaguarão, Vitor Hugo (mencionado duas vezes), Padre Themudo (fundador do Cemitério das Irmandades - mencionado duas vezes), jazigo da Família Gonçalves, jazigo da Família Bandeira, Coronel Manuel Marques de Souza (mencionado duas vezes), Padre Pereira Pagliani, Carlos Barbosa (foi um médico e político brasileiro, governador do Rio Grande do Sul durante a República Velha, senador, deputado e secretário de Estado mencionado três vezes). Outros mencionaram que a história geral é interessante, assim como a estrutura e arquitetura presente no Cemitério das Irmandades.

Cabe salientar que durante a aplicação da pesquisa, majoritariamente, abordou-se pessoas que estavam saindo da capela na finalização da missa e também, saindo do cemitério. Assim, ao finalizar a aplicação do questionário, muitos dos entrevistados relataram que até 
então não haviam parado para observar a arte, a história, a arquitetura e o patrimônio que o Cemitério das Irmandades possuía, e imediatamente ao fim da conversa retornaram ao Cemitério para apreciar esse novo olhar despertado pela pesquisa. Após essa nova visita, alguns retomaram o diálogo com os pesquisadores com diversas indagações sobre a simbologia da arte tumular e história do Cemitério.

\section{Considerações Finais}

Espera-se que o "Roteiro Turístico no Cemitério das Irmandades" contribua para os processos de ensino-aprendizagem do curso de Tecnologia e Gestão de Turismo através da motivação, do incentivo à criatividade na criação de novos roteiros turísticos, na possibilidade de atuação profissional na área, mesmo que em âmbito acadêmico, bem como, na vivência da teoria em experiências práticas. Da mesma forma, espera-se contribuir com a consolidação do trade turístico do município de Jaguarão ao proporcionar um novo roteiro turístico pronto para ser ofertado aos moradores locais e turistas. Acredita-se ainda que possa haver uma apropriação do espaço cemiterial pela comunidade, já que o projeto de ensino contribui para demonstrar a importância cultural que o Cemitério das Irmandades possui na comunidade jaguarense.

\section{Referências}

AFONSO, Liliane Rosa Gomes. Turismo Cemiterial: O cemitério como espaço de lazer. Monografia (Curso de Turismo). Instituto de Geociências, Universidade Federal de Minas Gerais, Belo Horizonte, 2010.

ARAUJO, Thiago Nicolau de. Espaço das representações da morte: Arte tumular como expressão da cultura. ANAIS DO IV ENCONTRO NACIONAL DO GT HISTÓRIA DAS RELIGIÕES E DAS RELIGIOSIDADES - ANPUH - Memória e Narrativas nas Religiões e nas Religiosidades. Revista Brasileira de História das Religiões. Maringá (PR) v. V, n.15, jan/2013. ISSN 1983-2850. Disponível em http://www.dhi.uem.br/gtreligiao/pub.html

BARRETTO, Margarita. Manual de Iniciação ao Estudo do Turismo. $8^{\circ}$ ed. São Paulo: Papirus, 1995.

BORGES, Maria Elizia. Arte funerária no Brasil (1890-1930): ofício de marmoraristas Italianos em Ribeirão Preto. Belo Horizonte: Editora C/ARTE, 2002.

BORGES, Maria Elizia. Imagens Devocionais nos Cemitérios do Brasil. In: XI Encontro da Associação Nacional de Pesquisadores em Artes Plásticas, 2001, São Paulo. ANPAP na Travessia das Artes - São Paulo: ANPAP, 2001. v.01. p. 10-15

BRASIL. INSTITUTO PATRIMÔNIO HISTÓRICO E ARTÍSTICO NACIONAL (IPHAN). Patrimônio Imaterial. Disponível em: 
<http://portal.iphan.gov.br/portal/montarPaginaSecao.do?id=10852\&retorno=paginaIphan>. Acesso em: 27 fev. 2015.

CARVALHO, Luiza Fabiana Neitzke de. ENTRE A LEMBRANÇA E O ESQUECIMENTO: implicações do descaso patrimonial para arte funerária do Rio Grande do Sul. in: Encontro da Associação Nacional de Pesquisadores em Artes Plásticas “entre territórios”, 19, 2010, Cachoeira. Anais do Encontro da ANPAP - Associação Nacional de Pesquisadores em Artes Plásticas, Cachoeira, BA, 20 a 25 de setembro de 2010. Salvador: Edufba, 2010. p. 540 - 553.

CASTRO, Elisiana Trilha. (2008) Cemitérios, nosso patrimônio nacional: ação do IPHAN com relação ao patrimônio funerário brasileiro. In: ENCONTRO DA ASSOCIAÇÃO BRASILEIRA DE ESTUDOS CEMITERIAIS, 4., Goiânia p. 1-9.

DEL PUERTO, Charlene Brum; BAPTISTA, Maria Luisa Cardinale. Espaço cemiterial e Turismo: campo de ambivalência da vida e morte. Revista Iberoamericana de Turismo RITUR, Penedo, vol. 5, n.1, p. 42-53, 2015. Disponível em: <http://www.seer.ufal.br/index.php/ritur/article/download/1611/1307> Acesso em 17 jul. 2017.

DEL PUERTO, Charlene Brum. TURISMO EM CEMITÉRIO. O Cemitério como Patrimônio e Atrativo Turístico, considerando a Trama Morte e Vida nas Necrópoles. 2016. 156f. Trabalho de conclusão de curso (Dissertação) Programa de Mestrado em Turismo, Universidade de Caxias do Sul, Rio Grande do Sul, 2016.

FERREIRA, Liciane Rossetto. Turismo de Fait Divers: Morbidez ou Nekrophilia. In: PANOSSO NETO, Alexandre; ANSARAH, Marilia Gomes dos Reis. Segmentação de Mercado Turístico: Estudos, Produtos e Perspectivas. Barueri: Manole, 2009. Cap. 21. p. 349-364

HAHNE, Letícia Conceição. Estudo sobre a aplicabilidade do turismo cemiterial em Curitiba. Escola de Negócio, Universidade Positivo (Monografia em Turismo), Curitiba, 2010.

HIPÓLITO, Paulo. Uma breve história dos cemitérios. 2011. Disponível em: $<$ http://www.historiaehistoria.com.br/materia.cfm?tb=artigos\&id=148\#_ftn8>. . Acessado em Junho de 2013.

JORNAL CORREIO DO POVO. “Aumenta devoção às milagreiras". CORREIO DO POVO, Porto Alegre, 3 nov. 1998. Cidades. p. 16

MARTINS, Roberto Duarte. A ocupação do espaço na fronteira Brasil-Uruguai: a construção de Jaguarão. Espanha: Universitat Politécnica de Catalunya, 2001

MUMFORD, Lewis. A cidade na história: suas origens, transformações e perspectivas. 4 ed. São Paulo: 1998. M. Fontes. 741p.

POULOT, Dominique. Um Ecossistema do Patrimônio. In: CARVALHO, C. S. de; GRANATO, M; BEZERRA, R. Z; BENCHETRIT, S. F. (orgs.). Um Olhar Contemporâneo sobre a Preservação do Patrimônio Cultural Material. Rio de Janeiro: Museu Histórico Nacional, 2008, pp. 26-43. 
PRATS, Llorenç. El Concepto de Patrimonio Cultural. Política y Sociedad, (27): 63-76, 1998.

QUEIROZ, Francisco. Os cemitérios históricos e o seu potencial turístico em Portugal. 2007. Disponível em: < http://21 gramas.pt/Uploads/17480711200709.pdf>. Acesso em Maio 2012.

SCHIMITT, Jean Claude. Os vivos e os mortos na sociedade medieval. São Paulo: Cia. Das Letras, 1999. 300p.

SOARES, Eduardo Alvares de Souza. Igreja Matriz do Divino Espírito Santo da Cidade de Jaguarão. Jaguarão: Evangraf, 2011.

VISSIÈRE, Séverine Fargette. Os animados cemitérios medievais. 2013. Disponível em: <http://www2.uol.com.br/historiaviva/reportagens/os_animados_cemiterios_medievais.html. Acesso em jul. 2013.

VOVELLE, Michel. Imagens e Imaginários na História: Fantasmas e certezas nas mentalidades desde a Idade Média até o século XX. São Paulo/SP: Editora Ática, 1997. 